\title{
PERLINDUNGAN HUKUM BAGI PEKERJA RUMAH TANGGA
}

\author{
Rini Rejeki Susilowati
}

\begin{abstract}
The torture that resulted in the death of the Helper / Domestic Worker (PRT) is a crime against humanity that can not be tolerated anymore, such a condition indicates that Domestic Helper has lost Autonomy and Ownership of him can even be caught in the status of a "slave" is the most vulnerable marginal group to get acts of violence from employers ILO Convention No. 189 on the proper work of domestic servants is a legal protection for domestic workers worldwide, but the existence of ILO Convention 189 does not necessarily concretely as a legal umbrella before it is ratified through the formal legal system in Indonesia, until now Law no. 13 of 2003 on employment does not explicitly recommend about domestic workers, especially concerning the aspect of legal protection as long as the need to realize the protection of Domestic Workers.
\end{abstract}

Keywords : Legal Protection, Domestic Worker, The Existence Of ILO Convention 189

\section{PENDAHULUAN}

Penyiksaan yang mengakibatkan kematian pembantu/pekerja rumah tangga (PRT) adalah kejahatan terhadap kemanusiaan yang tidak dapat ditolenr lagi Ironisnya, di Indonesia daftar korban PRT akibat kekerasan yang dilakukan oleh majikan masih terus berlangsung dari hari ke hari. Salah satu contoh kasus Yani Mulyaningsih (39), Casti (49), dan Resti (19) di rumah kawasan Sunter, Tanjung Priok yang dianiaya oleh majikannya. Nasib tragis Yani Mulyaningsih, Casti, dan Resti dan sekaligus Pekerja Rumah Tangga yang lain merupakan gambaran betapa dengan mudahnya majikan melakukan tindak kekerasan terhadap PRT bahkan sampai pada hilangnya nyawa seseorang yang menjadi korban. Kondisi seperti ini menunjukkan bahwa Pembantu Rumah Tangga (PRT) telah kehilangan otonomi

* Rini Rejeki Susilowati, Dosen Fakutas Hukum Universitas 17 Agustus 1945 Semarang dapat dihubugi melalui email : Redjekisusilowati (a)gmail.com dan kepemilikan atas dirinya dan bahkan dapat dikatakan terjebak dalam status sebagai 'budak". Dengan demikian nampak bahwa Pembantu Rumah Tangga (PRT) merupakan kelompok marginal yang paling rentan mendapatkan tindak kekerasan dari majikannya. Kekerasan tersebut antara lain penganiayaan, perkosaan, pelecehan seksual dan pembunuhan, dan bentuk kekerasan lainya yang menyentuh nilainilai kemanusiaan.

Jumlah Pekerja Rumah Tangga di Indonesia sangat tinggi baik Pekerja Rumah Tangga (PRT) migran maupun domestik yang merupakan sumber utama ekonomi keluarga miskin. Estimasi ILO tahun 2009 menunjukkan Pekerja Rumah Tangga (PRT) yang sebagian besar $(90 \%)$ perempuan dan anak-anak, merupakan kelompok kerja yang secara global terdapat sekitar 100 juta di dunia, di antaranya sekitar enam juta merupakan Pekerja Rumah Tangga migran dari Indonesia sedangkan sekitar tiga juta pekerja domestik. Dengan banyaknya Pekerja Rumah Tangga (PRT) secara tidak 
langsung memberikan kontribusi bagi pendapatan negara. ${ }^{1}$

Dari sini nampak kesenjangan yang luar biasa terhadap Pekerja Rumah Tangga (PRT) dilihat dari satu sisi keberadaannya sangat dibutuhkan terutama dalam kehidupan keluarga dan menjadi salah satu devisa negara, namun di sisi lain keberadaan dan jasa mereka diabaikan dan dilpandang sebelah mata, hal ini terbukti dengan tidak adanya kejelasan regulasi atau paying hukum yang dapat memberikan perlindungan bagi pekerjaan mereka. Dan paparan tersebut di atas, penlu untuk dikaji eksistensi dan urgensitas perlindungan hukum terhadap Pekerja Rumah Tangga.

Selain itu hingga kini eksistensi hukum tentang PRT masih menjadi polemik dalam ranah perdebatan mengenai kategorisasi. Dalam arti, apakah PRT termasuk kategori buruh / pekerja atau bukan. Undang Undang Nomor 13 tahun 2003 tentang Ketenagakerjaan memberikan perlindungan hukum bagi PRT?

Dari uraian Latar Belakang Masalah tersebut diatas dapat dirumuskan suatu masalah yaitu:

1. Bagaimana Undang-Undang nomor 13 tahun 2003 tentang tenagakerjaan memberikan perlindungan hukum bagi PRT ?

2. Bagaimana langkah hukum yang harus dilakukan dalam upaya memberikan perlindungan hukum bagi PRT?

\section{PEMBAHASAN}

\section{Perlindungan Hukum Pembantu Rumah Tangga dalam Perspektif Undang- Undang No.13 Tahun 2003 tentang Ketenagakerjaan.}

Pembantu Rumah Tangga (PRT) berhak mendapat kondisi kerja yang layak. ILO Indonesa Jaminan hak-hak PRT th 2009 menghasilkan Konvensi ILO No. 189

1 http//www.hrw.org/news/2010/02/12. Indonesia Jaminan hak-hak PRT th 2009
Mengenai Kerja Layak Pembantu Rumah Tangga (PRT).Konvensi ini merupakan perlindungan bagi PRT di seluruh dunia. Setelah melalui perjuangan yang panjang, akhimya Konferensi tahunan ILO ke - 100 menghasilkan Konvensi ILO No.189 Mengenai Kerja Layak Pembantu Rumah Tangga (PRT). Konvensi yang merupakan perlindungan bagi pembantu rumah tangga di seluruh dunia iini akan menjadi landasan untuk memberi pengakuan dan menjamin Pembantu Rumah Tangga mendapatkan kondisi kerja layak sebagaimana pekerja di sektor lain. ${ }^{2}$

Namun demikian keberadaan Konvensi ILO No. 189 tidak serta merta dirasakan secara konkrit sebagai payung perlindungan sebelum diratifikasi melalui system perundangan formal di Indonesia. Hingga kini belum ada undang- undang yang secara khusus mengatur tentang PRT. Apakah Undang-Undang No.13 Tahun 2003 memberikan perlindungan pada PRT, melalui makalah ini substansi persoalan tersebut akan dikaji.

Interpretasi pemerintah terhadap UU No.13 Tahun 2003 tentang Ketenaga kerjaan tidak menjangkau para PRT ke dalam sistem perundangan umum mengenai hubungan kerja. Kendati "pekerja" didefinisikan pada Pasal 1 sebagai "seseorang yang bekerja untuk mendapatkan upah atau bentuk imbalan lain". Pemerintah menyatakan, majikan pekerja rumah tangga bisa tergolong "pemberi kerja", ia bukan badan usaha dan dengan demikian bukan "pengusaha" di dalam artian UU tersebut Karena PRT dianggap tidak dipekerjakan oleh "pengusaha", mereka tidak diberikan perlindungan yang diberikan oleh undangundang terhadap pekerja lainnya. Disamping itu, mereka tidak diberi akses terhadap mekanisme penyelesaian perselisihan kerja, seperti pengadilan

\footnotetext{
2 http://www.gajimu.com/main/Tentangwanita/konvensi-ilo-seputar-hak-pembanturumah-tangga-prt
} 
industrial yang dibentuk menurut UndangUdang No. 2 Tahun 2004 tentang Penyelesaian Perselisihan Hubungan Industrial. Berdasarkan penafsiran terhadap substansi UU No.13 Tahun 2003 tersebut dengan demikian secara hukum keberadaan PRT tidak mendapatkan perlindungan hukum.

Upaya memberikan perlindungan hukum terhadap Pembantu Rumah Tangga. Secara yuridis, PRT memang bebas, sebab negara kita melarang perbudakan dan perhambaan. Tapi dan kacamata sosiologis, yang terjadi justru sebaliknya PRT tidak bebas sebagai orang yang memiliki keterbatasan bekal hidup selain tenaganya, PRT terpaksa bekerja pada orang lain dalam hal ini pemberi kerja yang memiliki otoritas menentukan syarat-syarat kerja. Relatif rendahnya tingkat pendidikan menutup kemampuan PRT mengekpos hak-haknya serta tak dapat merespon berbagai informasi yang dapat meningkatkan taraf hidupnya. Selama aturan main hubungan PRT dengan pemberi kerja diserahkan kepada kedua belah pihak, maka sukar dicapai suatu keseimbangan kepentingan yang mengedepankan nilai-nilai keadilan.

Sampai saat ini belum satupun lembaga atau yayasan penyalur PRT, memelopori penggarapan nasib para PRT dan sisi perlindungan hukum dan pemberdayaan. Dalam dunia akademikpun sangat langka menemukan hasil penelitian yang secara tematis mengangkat persoalan PRT. Bahkan pemerintahpun tidak pemah menggagas kampanye untuk membangkit kan kepedulian terhadap PRT. Namun demikian terdapat beberapa hal yang barangkali patut diagendakan sebagai upaya berarti untuk memberikan perlindungan terhadap PRT antara lain:

a. Law Reform (Refomiasi Hukum), ${ }^{3}$ pembaruan hukum yang diformulasikan dalam berbagai kebijakan berbasis keberpihakan kepada PRT dalam

3 Munir, Pengorganisasian Buruh Perempuan, Makalah dipresentasikan di LSH Surabaya,1998 kerangka perlindungan dan pemberdaya an serta pembinaan hubungan kerja. Law Reform ini dilakukan terhadap Undang-Undang No. 13 tahun 2003 sebagai hasil evalusi dan pengkajian atas realitas hubungan PRT dengan pemberi kerja berikut problem yang menyertainya. Dengan adanya Konvensi ILO No. 189, merupakan momentum bagi pemerintah di bidang hukum untuk segera melakukan ratifikasi bahkan lebih penting dan mendasar sebagai wujud komitmen dan konsistensinya, pemerintah segera membentuk perundang-undangan (law making) yang khusus memberikan perlindungan terhadap PRT.

b. Advocacy, mengangkat ke permukaan kasus-kasus PRT agar memperoleh respon banyak pihak guna menjadi agenda dalam upaya perubahan ke arah yang lebih baik.

c. Paralegal, sebagai bentuk penyadaran hukum dan aksi untuk melindungi diri PRT dad berbagai tekanan pemberi kerja.

d. Perlu dibentuk pusat-pusat pelayanan sebagai bagian dan bentuk peng organisasian, termasuk upaya untuk menggagas terbentuknya organisasi senkat pekeija khusus PRT. Pembentuk an serikat pekeija dalam hal ini tidak berarti menciptakan kaidah dari tidak ada menjadi ada tetapi juga menempat kan komunitas PRT secara afiliatif organisatoris terhadap organisasi Serikat Pekerja yang sudah mapan, seperti SPSI, SARBUMUSI dan sebagainya.

Undang-Undang No. 13 tahun 2003 tentang Ketenagakerjaan, khususnya pasal 1 ayat (1-4) tentang pengertian ketenaga kerjaan, tenaga kerja, pekerja/buruh dan pemberi kerja, dari ketentuan pasal ini sudah jelas definisi hukumnya sehingga Pekerja Rumah Tangga (PRT) telah memenuhi unsur yaitu setiap orang yang mampu memenuhi pekerjaan guna 
menghasilkan barang / jasa dan bekeija dengan menerima upah. Namun apabila dilihat di dalam pasal 1 ayat (5) tentang hubungan kerja adalah hubungan antara pengusaha dan pekerja/buruh berdasarkan perjanjian kerja yang mempunyai unsur pekerjaan, upah dan perintah. Di sinilah justru letak permasalahannya apakah kedudukan majikan dapat disamakan dengan pengusaha yang jelas berbadan hukum. Di samping mekanisme penyelesaian sengketanya karena lembaga yang berwenang menyelesaikan sengketa atau yang mempunyai kompetensi absolut dalam Undang-Undang Ketenagakerjaan adalah pengadilan hubungan industrial. Dan lembaga ini tidak dapat menerima perselisihan antara Pekerja Rumah Tangga (PRT) dan majikan, oleh karena terbentur penafsiran hukum yang berbeda. Terkait permasalahan tersebut, maka Undang-Undang Ketenagakerjaan tidak menjangkau tentang Pekerja Rumah Tangga (PRT) sehinggga ketentuan yang ada di dalamnya pun tidak dapat mengatur permasalahan Pekerja Rumah Tangga (PRT). Sehubungan dengan ini Pemerintah DKI Jakarta telah mempunyai regulasi tentang Pekerja Rumah Tangga (PRT) yaitu Perda DKI No. 6 tahun 2004, pasal 1 ayat (17) Pramuwisma adalah tenaga kerja yang melakukan pekerjaan pada rumah tangga dengan upah tertentu. Regulasi tersebut hanya berbentuk Perda sehingga hanya berlaku pada daerah setempat oleh karena itu tidak dapat berlaku secara nasional.

Undang-Undang No. 23 tahun 2004 tentang Penghapusan Kekerasan Dalam Rumah Tangga, dalam pasal 1 huruf (C) yang dimaksud dengan lingkup rumah tangga meliputi salah satunya orang yang bekerja membantu rumah tangga dan menetap dalam rumah tangga tersebut. Sedangkan, dalam pasal 2 ditegaskan bahwa orang yang bekerja sebagaimana dimaksud pada huruf(c) dipandang sebagai angggota keluarga dalam jangka waktu selama berada dalam rumah tangga yang bersangkutan. Penegasan tersebut di atas, sebenarnya payung hukum terhadap PRT sudah ada atau sudah terliridungi dan segala bentuk kekerasan namun belum menyentuh permasalahan yang berkaitan dengan hubungan kerja, sehingga diperlukan peraturan perundang undangan yang lebih khusus mengatur hubungan kerja (Lex Specialis derogat lex Generalis).

\section{Langkah Hukum Yang Harus Dilakukan Dalam Upaya Memberikan Perlindung an Hukum Bagi PRT}

Banyak alasan normatif, hukum dan bahkan politis yang dapat menguatkan argumentasi bahwa peilindungan hukum terhadap Pekerja Rumah Tangga (PRT) sudah saatnya diatur dalam peraturan perundang undangan tersendiri. Pertama, keberadaan undang-undang tentang PRT sebagal wujud perlindungan hukum bagi PRT sebagai strating point bagi pemerintah untuk secara bertahap membawa para pekerja yang berada di sektor informal menjadi pekerja formal. Pergeseran ini penting karena membawa dampak positif bagi pekerjaan PRT yang semula harya merupakan pekerjaan domestik (mayoritas perempuan dan anak) menjadi pekerjaan yang bernilai ekonomi. Sehubungan dengan hal tersebut, Margaret Benston dalam bukunya The Political Economy for Women sebagaimana dikutip Yulianthi mengatakan, sudah saatnya pekerjaan domestik dipikirkan secara lebih serius dalam setiap analisis pekerjaan ekonomi sehingga akhirnya tidak disepelekan menjadi status marginal dan tidak eksis. Frederick Engles dalam bukunya The Origin of The Family, Private Property and State sebagaimana dikutip Yulianthi juga menyatakan pekerja perempuan menjadi ticiak terlihat secara ekonomi karena berakar dan adanya pembagian keija secara seksual dalam keluarga dan masyarakat. Selanjutnya, Mubyarto menambahkan bahwa perempuan tidak ada yang 
menganggur jika memasukkan kerja domestik sebagai pekerjaan. ${ }^{4}$ Pergeseran PRT ke sektor formal juga menjadi awal yang baik bagi pemerintah untuk secara bertahap menggeser pekerja di sektor informal lainnya ke wilayah formal. Kementerian Tenaga Kerja pernah mengatakan jumlah tenaga kerja informal mencapai $67 \%$ dan total tenaga kerja nasional. Dengan demikian akan memberi manfaat bagi negara yaitu terbukanya peluang peningkatan pendapatan negara setidaknya dari sektor pajak, membangun negara menjadi sinergis.

Di samping itu yang terpenting adanya pengakuan secara hukum atas jenis pekerjaan PRT, kesetaraan nilai pekeijaan, kesejahteraan dan kepastian hukum yang dapat memberikan perlindungan secara langsung kepada PRT karena dijamin oleh peraturan perundang-undangan.Kedua, Keberadaan undang-undang tentang PRT akan memperkuat posisi tawar (bargaining potition) Indonesia di mata negara lain terutama negara tujuan kerja (Singapura, Malaysia, Arab Saudi, dll) warga Indonesia dalam mendorong adanya regulasi yang lebih ketat terhadap perlindungan buruh migran Indonesia. Indonesia juga telah mengikuti konvensi intemasional bersama negara-negara ILO untuk membicarakan standar internasional baru mengenai penyediaan kondisi kerja yang layak bagi PRT pada bulan Juni 2010, namun sangat disayangkan komitmen Indonesia dalam konvensi tersebut hanya sebatas rekomendasi yang berarti tidak mempunyai "kekuatan mengikat". Sehubungan dengan hal tersebut, Shepard mengatakan "Pemerintah Indonesia berpeluang kehilangan kredibilitasnya karena meng isyaratkan keengganan memberikan dukungan terhadap keberadaan peranjian yang mengikat, dan dengan tidak bertindak cepat dalam menangani kasus-kasus yang

4 Yulianthi Muthmainah, Peneliti Komisi nasional Anti Kekerasan terhadap Perempuan, Kompas, 9 September 2011. berhubungan dengan Pekerja Rumah Tangga di luar negeri”. Dan sebaiknya Indonesia menunjukkan ketegasan kepemimpinan pada tahun 2010 ini untuk memulihkan kredibilitasnya dan segera mendukung peraturan perlindungan Pekerja Rumah Tangga (PRT) di dalam dan luar negeri. Dengan demikian kurang adanya perlindungan bagi PRT terutama buruh migran di mata negara lain, oleh karena itu PRT berada dalam posisi yang rentan terhadap kekerasan dan eksploitasi. Kondisi ini menjadi alasan yang mendasar perlunya segera terbentuk peraturan perundang undangan bagi PRT. Ketiga, Diskriminasi terhadap PRT itu dikarenakan mayoritas (90\%) perempuan dan anakanak, ada beberapa indikator diskriminasj terhadap PRT yaitu: kelompok marginal, kelompok sub ordinat, keiompok rentan, dan kelompok pekerja informal. Indikator diskriminasi terhadap PRT, secara sosial menunjukkan adanya stigmatisasi, atau pelabelan terhadap peran PRT yaitu kelompok marginal dilihat dari status social ekonomi merupakan kelompok kebanyakan yang berekonomi lemah dan terpinggirkan, sedangkan kelompok sub ordinat, PRT mengalami diskriminasi berlapis, lapis dalam konteks posisi dan kondisi sebagai perempuan, lapis perspektif PRT dalam masyarakat lapis hak warga negara. Terlebih lagi dengan adanya budaya/kultur yang sangat berpengaruh terutama budaya patriarkhi, yang menimbulkan ketidakadilan dan bias gender. Ketidakadilan gender termanifestasikan dalam berbagai bentuk ketidakadilan yaitu marginalisasi, subord inasi, pembentukan stereotipe, kekerasan, beban kerja lebih panjang dan lebih banyak (doube barden) serta sosialisasi ideologi nilai dan peran gender. ${ }^{5}$ Manifestasi ketidakadilan gender ini seringkali, hadir dalam keyakinan masing-masing orang,

5 Fakih Mansor, Analisis Gender dan Transformasi Sosial, Pustaka Pelajar, Yogyakarta 1999, hlm 12. 
keluarga, hingga pada tingkat negara dan politik global. Pada wilayah inilah sangat perlu dimasukkan perspektif keadilan gender.

Selanjutnya, ditegaskan oleh Jalaluddin Rahmat bahwa laki-laki cenderung mereproduksi hegemoni struktural gender dan seksualitas. ${ }^{6}$ Tidak berlebihan jika dikatakan bahwa ilmu pengetahuan beserta teori yang dibangun nya merupakan konstruksi kaum laki-laki, terlebih lagi jika kita percaya pada apa yang dikatakan Simone de Beauvoir seperti yang dikutip oleh Jalaluddin Rahmat bahwa "dunia itu memang hasil karya laki laki, dan perempuan adalah jenis kelamin kedua". Disinilah terjadi maskulinisasi epistemo logis. ${ }^{7}$ PRT masuk dalam kategori kelompok rentan, fenomena sosial yang diskriminatif tersebut mengakibatkan PRT rentan terhadap kekerasan baik kekerasan fisik maupun psikologis (penganiayaan, pembunuhan eksploitasi, kompensasi yang tidak layek, tidak punya posisi tawar, dan lain-lain). PRT tidak mempunyai bergaining posisi sehingga kedudukannya sangat lemah dan tidak ada perlindungan hukum. Pekerja Rumah Tangga termasuk dalam kelompok pekerja informal, diskriminasi tertiadap PRT menyebabkan pekerjaan PRT tidak bernilai ekonomi. Pekerja Rumah Tangga dianggap bertanggung jawab untuk kegiatan reproduksi (melahirkan, mengasuh anak, bekerja di wilayah domestik) dilihat dari jenis pekerjaannya dan status sosial, namun pada hakikatnya PRT sangat urgen dalam kehidupan keluarga dan sudah selayaknya mereka mendapatkan hak, perlindungan dan manfaat yang sama seperti pekeija lainnya yang bernilai ekonomi. Dengan terbentuknya peraturan perundangundangan memberikan pengakuan bahwa

6 Ilyas Hamim, Perempuan Tertindas Kajian Hadis Misoginis, PSW IAIN Sunan Kalijaga, Yogyakarta dengan the Asia Foundation, Jakarta XXI, 2005, hlm 13.

7 Rahmat Jalalludin, Dan Psikologi Anfrosenfris ke Psikologi Feminis, Jumal Ulumul Quran, 1994, hlm. 17.
PRT setara nilainya dengan pekerjaan lainnya sehingga terwujud kesejahteraan bagi PRT. PRT selama ini didasarkan atas kepercayaan dan tidak tertulis oleh karena itu track record atau identitas Pekerja Rumah Tangga harus jelas baik identitasnya maupun kredibilitasnya. Hal ini untuk menghindari PRT yang "nakal atau bahkan melakukan tindak pidana (pencurian, pembunuhan, penculikan, pelecehan seksual, pemerkosaan) yang bervariasi modus operandinya. Keterlibatan penyedia jasa informasi PRT harus benar-benar memberikan data yang akurat (terdokumentasi dengan baik) dan ini tertuang dalam perjanjian kerja yang menjadi dasar dalam hubungan kerja. Sistem pengawasan juga dapat dijalankan dengan lebih efektif karena ada payung hukum yang memadai bagi petugas di lapangan maupun peran serta dari masyarakat Hal ini akan dapat terealisir dengan baik manakala ada regulasi yang menjadi payung hukumnya.

\section{KESIMPULAN}

Keberadaan Konvensi ILO No. 189 mengenai kerja layak pembantu rumah tangga yang merupakan perlindungan bagi Pembantu Rumah Tangga di seluruh dunia akan menjadi landasan untuk memberi pengakuan dan menjamin Pembantu Rumah Tangga mendapat kondisi kerja layak sebagaimana Pekerja disektor lain, namun keberadaan konvensi ILO No.189 tidak serta merta dirasakan secara kongkrit sebagai payung hukum perlindungan sebelum diratifikasi melalui sistim perlindunganformal di Indonesia. Serta UU No.13 tahun 2003 tentang ketenagakerjaan tidak menjangkau PRT ke dalam sistim perundangan umum mengenai hubungan kerja meskipun " Pekerka didefinisikan pada ps 1 sebagai "Seseorang yang bekerja untuk mendapatkan upah atau bentuk imbalan lain. 
Perlindungan terhadap pekerja Rumah Tangga perlu segera diwujudkan. Untuk itu pemerintah sebagi penetu kebijakan harus mempunyai good will dalam rangka mendorong terwujudnya perlindungan hukum bagi pekerja rumah tangga.

\section{DAFTARPUSTAKA}

Fakih Mansor, 1999. Analisis Gender dan Trans formasi Sosial, Pustaka Pelajar,Yogyakarta, Ilyas Hamim, , 2005 Perempuan Tertindas Kajian Hadis Misoginis, PSW IAIN Sunan Kalijaga Yogyakarta dengan the Asia Foundation, Jakarta, XXI.
Muthmainah Yulianthi, Peneliti Komisi Nasional Anti Kekerasan Terhadap Perempuan, Kompas, 9 September 2010.

Munir, 1998 Pengorganisasian Buruh Perempuan, Makalah, dipresentasi kan di LBH Surabaya, Rahmat Jalalludin, 1994. Dari Psikologi Antrosentris ke Psikologi Feminis, Jurnal Ulumul Quran, http://www.hrw.org/ja/news/2010/ $02 / 12$. Indonesia Jaminan hak-hak PRT th 2009

http://www.gajimu.com/main/Tentangwanita/konvensi-ilo-seputar-hakpembantu-rumah-tangga-prt 